\title{
ANALISIS KESENJANGAN KUALITAS PELAYANAN BERDASARKAN KEPUASAN PASIEN POLIKLINIK SARAF RS BHAYANGKARA SURABAYA
}

\author{
The Gap Analysis of Service Quality based on Customer Satisfaction in Neurological \\ Polyclinic Bhayangkara Hospital Surabaya
}

Luh Wayan Ema Natarini

IAKMI Jawa Timur, Indonesia

E-mail: luh.wayan.ema-2015@fkm.unair.ac.id

\begin{abstract}
Background: Neurological polyclinic service at Bhayangkara Hospital in Surabaya is one of polyclinics that has an increasing number of patient visits every year. To keep patients' loyalty towards a neurological polyclinic, the hospital must be able to meet patients' needs so that patients feel satisfied.

Aim: Therefore, it is necessary to conduct an assessment related to expectations and real service obtained by patients at the neurological polyclinic. The purpose of this study was to analyze the gap on the service quality and satisfaction level based on expectations and real service quality.

Method: The study design was cross sectional with 50 respondents as the sample taken by simple random sampling. The research method was a survey as a questionnaire instrument.

Results: The result showed that the satisfaction level of respondents in neurological polyclinic in general was very satisfying. The gap value of the overall research is that the service quality at the neuropathic polyclinics has a negative gap (-0.06). The service quality has not met patients' expectations.

Conclusion: In conclusion, the service quality is a vital part in Bhayangkara Hospital, Surabaya. The hospital can maintain their good image and patient visit if the service quality is excellent too. The hospital should improve the waiting room convenience and the discipline of their staffs to create better service quality.
\end{abstract}

Keywords: patients' satisfaction, gap analysis, quality dimension, service quality

\begin{abstract}
ABSTRAK
Latar Belakang: Pelayanan poliklinik saraf di Rumah Sakit Bhayangkara Surabaya merupakan salah satu poliklinik yang memiliki jumlah kunjungan pasien yang selalu meningkat setiap tahunnya. Untuk menjaga pasien tetap memilih produk pelayanan di poliklinik saraf, rumah sakit harus mampu memenuhi kebutuhan pasien sehingga muncul kepuasan.

Tujuan: Oleh karena, itu perlu dilaksanakan penilaian terkait harapan dan kenyataan pelayanan yang diperoleh pasien di poliklinik saraf. Tujuan penelitian adalah untuk menganalisis kesejangan pada kualitas pelayanan dan tingkat kepuasan berdasarkan harapan dan kenyataan pelayanan yang diperoleh pasien.

Metode: Desain penelitian adalah cross sectional dengan jumlah sampel 50 responden. Pengambilan sampel dilakukan secara simple random sampling. Metode penelitian adalah survei dengan instrumen kuesioner.

Hasil: Tingkat kepuasan responden di poliklinik saraf secara umum masuk ke dalam kategori sangat puas. Nilai kesenjangan secara keseluruhan kualitas pelayanan di poliklinik saraf memiliki nilai negatif $(-0,06)$. Hasil penelitian ini menunjukan bahwa kualitas pelayanan yang diberikan belum mampu memenuhi harapan responden.

Kesimpulan: Dapat disimpulkan bahwa kualitas pelayanan sangat penting di Rumah Sakit Bhayangkara, Surabaya. Rumah sakit ini dapat mempertahankan citra baik dan kunjungan pasien jika kualitas pelayanannya juga bagus. Rumah sakit tersebut perlu meningkatkan kenyamanan ruang tunggu dan disiplin karyawan untuk menciptakan kualitas pelayanan yang lebih baik.
\end{abstract}

Kata Kunci: analisis kesenjangan, dimensi kualitas, kepuasan pelanggan, kualitas pelayanan

\section{PENDAHULUAN}

Fasilitas pelayanan kesehatan di era globalisasi ini berlomba-lomba untuk memberikan pelayanan kesehatan yang optimal. Hal ini dikarenakan perkembangan ilmu pengetahuan dan teknologi kesehatan yang sangat pesat. Selain itu, masyarakat saat ini semakin kritis dalam memilih produk jasa yang digunakan. Masyarakat sebagai konsumen tidak hanya sekadar membeli suatu produk tetapi lebih menginginkan pelayanan kesehatan yang berkualitas sejak sebelum melakukan pembelian sampai setelah pembelian. 
Rumah Sakit Bhayangkara H. Samsoeri Mertojoso Surabaya merupakan fasilitas pelayanan kesehatan publik yang dimiliki oleh Kepolisian Daerah Jawa Timur yang berada di Kota Surabaya, Jawa Timur. Tipe rumah sakit ini adalah Rumah Sakit Umum tipe B. Terdapat 12 jenis pelayanan yang dapat diakses oleh masyarakat. Pelayanan poliklinik saraf merupakan salah satu jenis pelayanan yang memiliki jumlah kunjungan yang selalu meningkat setiap tahunnya. Jumlah kunjungan yang tinggi merupakan hal yang positif untuk Rumah Sakit Bhayangkara H. Samsoeri Mertojoso Surabaya. Untuk menjaga pasien tetap memilih produk pelayanan di poliklinik saraf, rumah sakit harus mampu memenuhi kebutuhan pasien atau memberikan pelayanan yang lebih dari yang diharapkan sehingga muncul kepuasan.

Menurut Kotler (2014) kepuasan pelanggan adalah perasaan yang muncul pada seorang pelanggan baik itu perasaan senang ataupun kecewa setelah pelanggan tersebut membandingkan antara hasil produk atau jasa yang diinginkan dengan hasil produk yang didapatkan. Tingkat kepuasan seorang pelanggan akan memberikan pengaruh terhadap minat pelanggan untuk menggunakan kembali pelayanan yang sama yang terdapat di poliklinik saraf. Pelanggan yang puas akan menjadi pelanggan yang loyal dan dapat pula pelanggan tersebut akan melakukan promosi secara tidak langsung kepada calon pelanggan lainnya (Diarti, et al., 2014). Mengukur tingkat kepuasan pasien dapat dilakukan dengan empat metode, antara lain: 1) Sistem keluhan dan saran, 2) Ghost shopping, 3) Lost customer analysis, dan 4) Survei kepuasan pelanggan (Heria, et al., 2016).

Untuk mewujudkan tingkat kepuasan pelanggan yang baik perlu adanya pemahaman mengenai harapan pelanggan oleh pihak penyedia pelayanan itu sendiri. Tanpa adanya pemahaman mengenai apa yang diharapkan pelanggan, sulit bagi penyedia pelayanan untuk mampu memberikan pelayanan yang memuaskan (Wedy, et al., 2016). Maka dari itu, untuk mengetahui tingkat kepuasan pelanggan perlu dilakukannya penilaian terhadap harapan dan kenyataan pelayanan yang diperoleh pasien di poliklinik saraf.

Bagi penyedia pelayanan, rumah sakit, menjaga kualitas pelayanan tidak dapat dilakukan hanya berdasarkan melihat hasil tingkat kepuasan pelanggan. Rumah sakit juga harus mengetahui ada atau tidaknya kesenjangan pada setiap dimensi kualitas pelayanan secara lebih detail. Berdasarkan hal tersebut tujuan dari penelitian ini adalah menganalisis tingkat kesenjangan antara harapan dan kenyataan yang diperoleh pasien di poliklinik saraf Rumah Sakit Bhayangkara H. Samsoeri Mertojoso Surabaya. Hasil dari pengukuran kesenjangan pelanggan dapat dijadikan dasar untuk mengetahui secara spesifik dimensi dalam kualitas pelayanan yang masih memiliki kekurangan. Dengan demikian, pihak rumah sakit dapat melakukan penyempurnaan guna meningkatkan kualitas pelayanan di poliklinik saraf.

Manfaat yang diperoleh dari penelitian ini adalah diketahuinya gambaran mengenai tingkat kesenjangan dan tingkat kepuasan pelanggan terhadap kualitas pelayanan diterima oleh pasien di poliklinik saraf. Selain itu, dapat menjadi bahan referensi terkait kepuasan pasien dan kesenjangan pelanggangan terhadap fasilitas pelayanan kesehatan.

\section{METODE}

Penelitian ini merupakan penelitian observasional karena peneliti tidak memberikan perlakukan kepada sampel. Desain penelitian yang digunakan adalah cross sectional. Pemilihan desain penelitian ini berdasarkan pengumpulan data yang dilakukan pada waktu yang bersamaan. Sampel dalam penelitian ini sebanyak 50 orang responden. Jumlah sampel yang digunakan mengikuti jumlah sampel minimal survei kepuasan pelanggan menurut Permenkes RI No 129 tahun 2008. Pengambilan sampel dilakukan secara simple random sampling. Dengan kriteria responden adalah pasien yang telah mendapatkan pelayanan di poliklinik saraf dan bersedia mengisi lembar kuesioner. Lokasi penelitian di poliklinik saraf Rumah Sakit Bhayangkara H. Samsoeri Mertojoso Surabaya. Metode penelitian adalah survey dengan menggunakan instrumen penelitian berupa kuesioner.

Pernyataan pada kuesioner berdasarkan pada model Service Quality (SERVQUAL) yang menilai lima dimensi kualitas pelayanan kesehatan. Lima dimensi kualitas pelayanan kesehatan tersebut adalah dimensi tangibles, reliability, assurance, responsiveness dan empathy(Zeithaml, et al., 1996). Penilaian setiap dimensi kualitas pelayanan menggunakan skala 1 sampai 4 (sangat tidak berharap sampai sangat berharap) untuk harapan dan skala 1 sampai 4 (sangat tidak puas sampai sangat puast) untuk kenyataan. Nilai pada setiap dimensi kualitas pelayanan akan dijumlahkan dan dicari rata-rata. Hasil perhitungan nilai rata-rata pada setiap dimensi kemudian dikategorikan ke dalam tingkat kepuasan (sangat tidak puas sampai sangat puas). Nilai untuk kesenjangan kualitas pelayanan diperoleh dari menghitung selisih antara nilai harapan dengan nilai kenyataan.Nilai positif $(+)$ pada penilaian kesenjangan diperoleh apabila skor kenyataan lebih besar dari skor harapan. Apabila skor harapan lebih besar daripada skor kenyataan maka akan diperoleh nilai negatif $(-)$. Semakin besar nilai selisih yang didapatkan maka dapat diketahui bahwa kenyataan yang dirasakan oleh responden masih jauh dengan yang harapan responden. Begitu pula sebaliknya, semakin kecil nilai selisih, maka pelayanan yang diberikan semakin mendekati harapan responden.

\section{HASIL DAN PEMBAHASAN}

Rumah Sakit Bhayangkara H. Samsoeri Mertojoso adalah rumah sakit umum milik Kepolisian Daerah Jawa Timur yang berlokasi di Kota Surabaya, Jawa Timur. Visi Rumah Sakit Bhayangkara $H$. Samsoeri Mertojoso adalah menjadi Rumah Sakit Bhayangkara yang terbaik dalam bidang pelayanan kesehatan dan kedokteran kepolisian. Adapun motto yang dipegang teguh adalah Melayani Sepenuh Hati. Selain itu, Rumah 
Sakit Bhayangkara H. Samsoeri Mertojoso adalah rumah sakit dengan status PK BLU penuh.

Rumah Sakit Bhayangkara H. Samsoeri Mertojoso memiliki 12 jenis pelayanan yang meliputi pelayanan di instalasi rawat inap, instalasi rawat jalan dan instalasi gawat darurat. Rumah sakit melayani baik pasien umum maupun pasien BPJS. Salah satu poliklinik yang selalu ramai oleh kunjungan pasien adalah poliklinik saraf. Dalam mempertahankan kualitas pelayanan di poliklinik saraf, maka pihak rumah sakit harus mengetahui tingkat kepuasan pasiennya. Dengan adanya pengukuran tingkat kepuasan pasien akan diketahui kenyataan mengenai kualitas pelayanan dari sudut pandang pasien. Selain itu, rumah sakit juga dapat menganalisis kesenjangan pada dimensi kualitas pelayanan yang dirasakan masih kurang sehingga dapat dilakukan perbaikan yang berorientasi pada harapan pasien (Supartiningsih, 2017).

Pasien poliklinik saraf yang menjadi responden berjumlah 50 orang. Responden merupakan pasien yang telah mendapatkan pelayanan dari poliklinik saraf, baik itu adalah pasien baru maupun pasien yang melakukan kunjungan ulang. Pasien yang bersedia menjadi responden terlebih dahulu diberikan penjelasan terkait penelitian dan telah menandatangi informed consent. Responden mengisi kuesioner secara mandiri namun tetap didampingi oleh peneliti. Tujuannya adalah untuk memudahkan konfirmasi apabila masih terdapat pertanyaan yang belum dipahami oleh responden. Adapun hasil penelitian terkait karakteristik dari responden pada penelitian ini disajikan pada Tabel 1.

Tabel 1. Distribusi Karakteristik Responden Poliklinik Saraf Rumah Sakit Bhayangkara H. Samsoeri Mertojoso Surabaya Tahun 2016

\begin{tabular}{lcc}
\hline Karakteristik & $\mathbf{n}$ & Persentase \\
\hline $\begin{array}{c}\text { Jenis Kelamin } \\
\text { Laki-laki }\end{array}$ & 20 & $40 \%$ \\
$\quad$ Perempuan & 30 & $60 \%$ \\
Kelompok Umur & & \\
18-25 tahun & 0 & $0 \%$ \\
26-35 tahun & 0 & $0 \%$ \\
36-45 tahun & 9 & $18 \%$ \\
>45 tahun & 41 & $82 \%$ \\
Pekerjaan & & \\
Tidak bekerja & 23 & $46 \%$ \\
Petani & 0 & $0 \%$ \\
PNS/TNI/POLRI & 10 & $20 \%$ \\
IRT & 5 & $10 \%$ \\
Wiraswasta & 12 & $24 \%$ \\
\hline
\end{tabular}

Berdasarkan hasil pemaparan Tabel 1, dapat diketahui bahwa karakteristik jenis kelamin responden mayoritas adalah perempuan, yaitu sebanyak $60 \%$ dan responden laki-laki sebanyak $40 \%$. Kelompok usia responden terdiri atas dua kelompok usia, yaitu kelompok usia 36-45 tahun sebanyak $17 \%$ dan kelompok usia lebih dari 45 tahun. Berdasarkan data tersebut dapat diketahui bahwa kelompok usia terbanyak adalah kelompok usia lebih dari 45 tahun. Hal ini menunjukkan bahwa kebutuhan yang tinggi pada pelayanan poliklinik terdapat pada orang-orang yang memasuki fase lanjut usia. Menurut Kowalska, et al. (2017) bertambahnya usia mengakibatkan terjadinya perubahan fungsi neuron kolinergik pusat. Di negara maju, bertambah tuanya usia menjadi penyebab meningkatnya kejadian terkait penyakit syaraf. Menurut Hermanti (2017) dalam penelitiannya menyatakan bahwa bahwa usia berkontribusi terhadap peningkatan kebutuhan terhadap pelayanan kesehatan. Semakin bertambah usia seseorang, maka tingkat kebutuhannya terhadap pelayanan kesehatan juga akan meningkat.

Karakteristik responden berdasarkan jenis pekerjaan terbagi menjadi empat kategori, yaitu ibu rumah tangga (IRT), PNS/TNI/POLRI, wiraswasta dan tidak bekerja. Berdasarkan hasil penelitian diketahui bahwa mayoritas responden masuk kedalam ketegori tidak bekerja (46\%). Banyaknya responden yang tidak bekerja merupakan para pensiunan dari pegawai negeri sipil.

Penilaian tingkat kepuasan pada penelitian ini mengacu pada lima dimensi kualitas pelayanan, yaitu dimensi tangible, reliability, assurance, responsiveness dan empathy (Zeithaml, et al., 1996). Setiap dimensi dinilai besar nilai harapan dan kenyataan pelayanan yang diperoleh pasien. Menurut Muala (2016) dimensi kualitas dalam pelayanan jasa merupakan kunci utama dalam menjaga manfaat dan hubungan dengan pelanggan untuk mewujudkan kepuasan bagi pelanggan. Dengan memahami setiap dimensi kualitas pelayanan yang terdapat didalam pelayanan yang diberikan, maka penyedia pelayanan juga akan mampu mengetahui diferensiasi pelayanan yang mereka tawarkan. Hasil penilaian harapan dan kenyataan setiap dimensi dalam penelitian disajikan pada Tabel 2

Pada kualitas pelayanan, dimensi tangible adalah dimensi yang menilai kualitas pelayanan berdasarkan fasilitas fisik, peralatan, pelaksana dan bahan/teknologi yang bisa dirasakan langsung oleh panca indra konsumen (Pena, et al., 2013). Sedangkan menurut Muala (2016), dimensi tangibel adalah dimensi kualitas pelayanan yang meliputi struktur perusahaan, fasilitas, alat dan media komunikasi. Pada penelitian ini, dimensi tangible yang menjadi penilaian adalah keadaan ruangan pelayanan, penampilan dokter dan perawat, ketersediaan papan petunjuk, ketersediaan alat medis, dan kondisi ruang tunggu di poliklinik saraf. Berdasarkan Tabel 2, diketahui bahwa sub-dimensi tangible yang mendapatkan nilai rata-rata tertinggi $(3,46)$ adalah penampilan dokter yang bersih dan rapi. Responden menilai dokter di poliklinik saraf telah menggunakan pakaian yang bersih dan rapi selama memberikan pelayanan. Dokter juga menggunakan tanda pengenal sehingga mudah dikenali. Sedangkan sub-dimensi yang mendapat nilai rata-rata terendah $(2,84)$ adalah ruang tunggu pasien. Ruang tunggu yang disediakan di poliklinik saraf masih belum mampu memberikan rasa nyaman kepada pelanggan. Tidak jarang pasien yang sedang menunggu merasa kepanasan.

Dimensi reliability adalah dimensi yang menilai kualitas pelayanan berdasarkan kemampuan penyedia pelayanan untuk 
memberikan pelayanan yang aman (sesuai dengan prosedur) dan efisien kepada setiap pelanggannya. (Pena, et al., 2013). Pada pelayanan kesehatan, pelayanan yang aman yang dimaksud adalah pelayanan dari petugas kesehatan yang mampu memberikan rasa aman dan nyaman, sehingga pasien memiliki kepercayaan terhadap pengobatan atau perawaratan yang diberikan. Dalam penelitian ini, penilaian pada dimensi reliability meliputi, prosedur penerimaan pasien, ketepatan waktu datang dokter dan perawat, kesiapan dokter dalam melayani pasien, penjelasan dokter terkait keadaan pasien, kejelasan dokter dalan menjelaskan tindakan yang akan dilakukan (informed consent) dan kesesuaian perawat dalam memberikan pelayanan.

Tabel 2. Distribusi Nilai Rata-rata Kepuasan Pasien Poliklinik Saraf Rumah Sakit Bhayangkara H. Samsoeri Mertojoso Surabaya Tahun 2016

\begin{tabular}{|c|c|c|c|c|}
\hline \multirow{3}{*}{ Dimensi } & \multicolumn{4}{|c|}{ Nilai } \\
\hline & \multicolumn{2}{|c|}{ Kenyataan } & \multicolumn{2}{|c|}{ Harapan } \\
\hline & 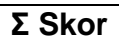 & Rata-Rata & $\Sigma$ Skor & Rata-Rata \\
\hline \multicolumn{5}{|l|}{ Tangible } \\
\hline Ruang tertata rapi dan bersih & 168 & 3,36 & 174 & 3,48 \\
\hline Ruang nyaman & 165 & 3,30 & 171 & 3,42 \\
\hline Penampilan dokter bersih dan rapi & 173 & 3,46 & 164 & 3,28 \\
\hline Penampilan perawat bersih dan rapi & 172 & 3,44 & 170 & 3,40 \\
\hline Memiliki papan petunjuk yang jelas & 169 & 3,38 & 171 & 3,42 \\
\hline Alat medis yang lengkap & 165 & 3,30 & 177 & 3,54 \\
\hline Ruang tunggu nyaman & 142 & 2,84 & 171 & 3,42 \\
\hline \multicolumn{5}{|l|}{ Reliability } \\
\hline Prosedur penerimaan pasien & 172 & 3,44 & 172 & 3,44 \\
\hline Dokter datang tepat waktu & 165 & 3,30 & 170 & 3,40 \\
\hline Perawat datang tepat waktu & 174 & 3,48 & 167 & 3,34 \\
\hline Kesiapan dokter melayani pasien & 174 & 3,48 & 170 & 3,40 \\
\hline Penjelasan dokter terkait keadaan pasien & 173 & 3,46 & 176 & 3,52 \\
\hline $\begin{array}{l}\text { Kejelasan dokter menjelaskan tindakan yang akan } \\
\text { dilakukan }\end{array}$ & & & & \\
\hline dilakukan & 177 & 3,54 & 174 & 3,48 \\
\hline Perawat memberikan pelayanan sesuai & 168 & 3,36 & 179 & 3,58 \\
\hline \multicolumn{5}{|l|}{ Responsiveness } \\
\hline Dokter menanyakan keluhan pasien & 180 & 3,60 & 180 & 3,60 \\
\hline Dokter memberi kesempatan pasien bertanya & 176 & 3,52 & 174 & 3,48 \\
\hline Penjelasan dokter mengenai penyakit & 180 & 3,60 & 180 & 3,60 \\
\hline Penjelasan dokter mengenai pengobatan & 179 & 3,58 & 171 & 3,42 \\
\hline Perawat tanggap melayani pasien & 173 & 3,46 & 177 & 3,54 \\
\hline Perawat meminta persetujuan pasien & 173 & 3,46 & 174 & 3,48 \\
\hline Pelayanan sesuai prosedur & 176 & 3,52 & 180 & 3,60 \\
\hline \multicolumn{5}{|l|}{ Assurance } \\
\hline Dokter mampu menetapkan diagnosis & 177 & 3,54 & 174 & 3,48 \\
\hline Pasien merasa aman & 175 & 3,50 & 173 & 3,46 \\
\hline Memberikan penjelasan mengenai obat & 176 & 3,52 & 176 & 3,52 \\
\hline Terdapat catatan medis pasien & 171 & 3,42 & 179 & 3,58 \\
\hline Kerahasiaan pasien & 170 & 3,40 & 174 & 3,48 \\
\hline Alat-alat medis kondisi baik & 173 & 3,46 & 173 & 3,46 \\
\hline Biaya terjangkau & 175 & 3,50 & 180 & 3,60 \\
\hline \multicolumn{5}{|l|}{ Empathy } \\
\hline Memanggil nama pasien dengan benar & 178 & 3,56 & 182 & 3,64 \\
\hline Perawat sungguh-sungguh & 170 & 3,40 & 174 & 3,48 \\
\hline Waktu pelayanan cukup & 172 & 3,44 & 175 & 3,50 \\
\hline Dokter mendengar keluhan pasien & 177 & 3,54 & 184 & 3,68 \\
\hline Dokter nampak tenang & 173 & 3,46 & 190 & 3,80 \\
\hline Petugas sopan dan ramah & 178 & 3,56 & 186 & 3,72 \\
\hline Memberi informasi jelas ke pasien & 177 & 3,54 & 179 & 3,58 \\
\hline
\end{tabular}

Pada Tabel 2, diketahui bahwa sub-dimensi reliability yang mendapatkan nilai rata-rata tertinggi $(3,54)$ adalah kejelasan dokter dalam menjelaskan tindakan yang akan diberikan (informed consent). Dalam memberikan pelayanan, dokter di poliklinik saraf Rumah Sakit Bhayangkara H. Samsoeri
Mertojoso Surabaya terlebih dahulu memberikan penjelasan mengenai tindakan apa yang akan diberikan kepada pasien. Hal ini sesuai dengan pendapat Caresya, et al (2016) bahwa dokter wajib memberikan penjelasan kepada pasien sebelum melaksanaan tindakan medis dengan bahasa yang 
mudah dipahami oleh pasien. Sedangkan untuk nilai rata-rata terendah $(3,30)$ terdapat pada sub-dimensi ketepatan waktu kedatangan dokter. Berdasarkan nilai tersebut diketahui bahwa masih terdapat kejadian dokter yang datang tidak tepat waktu, sesuai dengan jam pelayanan yang telah disepakati. Dimensi responsiveness adalah dimensi yang menunjukkan kemauan atau inisiatif dari pemberi pelayanan untuk memberikan bantuan serta memberikan pelayanan yang cepat, tanggap, serta sesuai dengan kebutuhan pelanggan. Pada kualitas pelayanan kesehatan, aspek yang dinilai pada dimensi responsiveness secara rinci adalah sebagai berikut: menanyakan keluhan pasien, pemberian kesempatan pasien untuk bertanya, penjelasan dokter mengenai penyakit, penjelasan dokter mengenai pengobatan, ketanggapan perawat dalam melayani pasien, meminta persetujuan pasien oleh perawat, dan kesesuian pelayanan dengan prosedur.

Berdasarkan hasil penelitian yang disajikan pada Tabel 2 diketahui bahwa sub-dimensi dengan nilai rata-rata tertinggi pada dimensi rresponsiveness adalah dokter menanyakan keluhan pasien $(3,60)$ dan penjelasan dokter mengenai penyakit $(3,60)$. Dokter di poliklinik saraf dirasakan telah cepat dalam menanggapi setiap keluhan pasien sehingga pasien merasa nyaman dan puas dengan pelayan yang diberikan. Selain itu penjelasan dokter mengenai penyakit yang diderita pasien dapat dipahami oleh pasien dengan baik. Sedangkan sub-dimensi dengan nilai rata-rata terendah pada dimensi rresponsiveness adalah ketanggapan perawat melayani pasien $(3,46)$ dan perawat meminta persetujuan pasien $(3,46)$. Hal ini menunjukkan bahwa upaya memberikan pelayanan yang tanggap dan sesuai kebutuhan pasien oleh perawat di poliklinik saraf masih lebih rendah dibandingkan petugas kesehatan lainnya.

Dimensi assurance adalah dimensi di dalam kualitas pelayanan yang dalam penilaiannya merujuk pada sopan santun dan kemampuan penyedia pelayanan untuk meyakinkan pelanggan sehingga muncul rasa percaya dari pelanggan kepada penyedia pelayanan (Pena, et al, 2013). Dimensi assurance adalah salah satu dimensi yang memiliki pengaruh yang penting terhadap kualitas pelayanan. Selain itu, hubungan personal yang baik antara pasien dengan dokter dan perawat akan meningkatkan penilai pada unsur yang dinilai, yaitu kemampuan dokter untuk menetapkan diagnosis, kenyamanan pasien, pemberian penjelasan mengenai obat, ada tidaknya catatan medis pasien, kondisi alat-alat medis, dan biaya pengobatan. Berdasarkan hasil penilaian responden pada tabel 2. diketahui bahwa sub-dimensi dengan nilai ratarata tertinggi $(3,54)$ adalah kemampuan dokter untuk menetapkan diagnosis. Pasien cenderung merasa puas saat mendapatkan dokter yang memberi perawatan adalah dokter yang memiliki keterampilan yang baik dalam berkomunikasi dan kompeten dalam menentukan diagnosis penyakit (Ha, et al., 2010). Sedangkan untuk nilai rata-rata terendah $(3,40)$ terdapat pada sub-dimensi kerahasiaan pasien. Belum semua pasien merasa terjamin kerahasiaannya saat berobat di poliklinik saraf.

Dimensi empathy adalah dimensi yang berkaitan dengan upaya dari penyedia pelayanan untuk menunjukkan minat, perhatian dan rasa ingin membantu secara individu kepada para pelanggan (Pena, et al., 2013). Dalam penelitian ini, subdimensi empathy yang dinilai adalah cara memanggil nama pasien, kesungguhan perawat, waktu pelayanan, kesediaan dokter dalam mendengarkan keluhan pasien, ketenangan dokter dalam memberikan pelayanan, kesopanan dan keramahan perawat, serta penyampaian informasi kepada pasien. Sub-dimensi empathy dengan nilai rata-rata tertinggi pada dimensi empathy adalah cara memanggil nama pasien $(3,56)$ serta kesopanan dan keramahan perawat $(3,56)$. Sedangkan sub-dimensi dengan nilai rata-rata terendah adalah kesungguhan perawat $(3,40)$. Pasien merasa masih terdapat beberapa perawat yang belum mendengarkan apa yang mereka sampaikan dengan saksama.

Penjumlahan hasil penilaian kenyataan pada tiap dimensi akan memunculkan hasil kategori tingkat kepuasan. Penggunaan nilai kenyataan sebagai dasar pengkategorian, karena nilai kenyataan adalah nilai yang muncul setelah pasien mendapatkan pelayanan. Selain itu nilai kenyataan juga menggambarkan keadaan kualitas pelayanan saat ini. Tingkat kepuasan responden pada penelitian ini dikelompokkan menjadi empat kategori, yaitu sangat tidak puas (nilai 1,00-1,75), kurang puas (nilai $1,76-2,50$ ), puas (nilai $2,51-3,25$ ), dan sangat puas (nilai 3,26-4,00). Hasil perhitung tersebut ditampilkan pada tabel 3 .

Tabel 3. Distribusi nilai kesenjangan tingkat kepuasan pasien poliklinik saraf Rumah Sakit Bhayangkara $\mathrm{H}$. Samsoeri Mertojoso Surabaya tahun 2016

\begin{tabular}{lcccc}
\hline \multicolumn{1}{c}{ Dimensi } & Kenyataan & Harapan & Nilai Kesenjangan & Keterangan \\
\hline Tangible & 3,30 & 3,42 & $-0,12$ & Sangat Puas \\
Reliability & 3,44 & 3,45 & $-0,01$ & Sangat Puas \\
Responsiveness & 3,53 & 3,53 & 0,00 & Sangat Puas \\
Assurance & 3,48 & 3,51 & $-0,03$ & Sangat Puas \\
Empathy & 3,50 & 3,63 & $-0,13$ & Sangat Puas \\
\hline Rata-rata Total & 3,45 & 3,51 & $-0,06$ & Sangat Puas \\
\hline
\end{tabular}

Terdapatnya kesenjangan dalam pemberian pelayanan merupakan tanda bahwa pelayanan yang diberikan oleh penyelenggara masih belum sesuai dengan keinginan konsumen. Dalam industri jasa, pelayanan konsumen merupakan hal yang vital bagi keberlangsungan penyedia layanan. Mengetahui besaran gap atau kesenjangan menjadi hal yang penting di dalam usaha penyediaan jasa 
terutama yang bergerak dibidang jasa kesehatan. Pengguna jasa kesehatan memiliki karakter dan kebutuhan yang berbeda satu sama lain sesuai dengan diagnosis penyakit. Maka dari itu, penyedia jasa harus peka terhadap respon, tanggapan dan kebutuhan pasien.

Berdasarkan Tabel 3, diketahui secara keseluruhan kualitas pelayanan di poliklinik saraf Polikinik Saraf Rumah Sakit Bhayangkara $\mathrm{H}$. Samsoeri Mertojoso Surabaya memiliki nilai kesenjangan negatif $(-0,06)$. Kualitas pelayanan yang diberikan belum mampu memenuhi harapan responden. Dengan kata lain, harapan responden terhadap kuliatas pelayanan masih lebih besar dibandingkan dengan kinerja pelayanan di polikinik saraf itu sendiri.

Pada dimensi kualitas pelayanan, empat dari lima dimensi memiliki nilai kesenjangan negatif. Hal ini menunjukkan bahwa nilai harapan pasien lebih besar dibandingkan dengan nilai kenyataan. Kualitas peyalanan Polikinik Saraf Rumah Sakit Bhayangkara H. Samsoeri Mertojoso Surabaya secara spesifik dinilai belum memberikan pelayanan yang memenuhi harapan responden. Urutan dimensi yang mendapat nilai minus dari yang terbesar hingga terkecil adalah reliability $(-0,01)$, assurance $(-0,03)$, tangible $(-0,12)$ dan empathy ($0,13)$. Dimensi dinilai telah sesuai antara harapan dengan kenyataan responden adalah dimensi responsiveness yang mendapatkan nilai kesenjangan 0.

Dimensi reliability memperoleh nilai kesenjangan yang sangat kecil. Dengan beberapa perbaikan di dalam sub-dimensinya akan dapat meningkatkan nilai kepuasan responden. Terdapat empat sub-dimensi telah mampu melebihi harapan responden. Keempat sub-dimensi tersebut adalah prosedur penerimaan pasien yang dianggap mudah sehingga tidak perlu menghabiskan waktu yang lama, perawat yang datang tepat waktu sesuai dengan jam pelayanan poliklinik, kesiapan dokter melayani pasien yang dinilai sudah baik, dan kemampuan dokter dalam memberikan penjelasan sebelum melakukan tindakan. Sedangkan pada tiga sub-dimensi lainnya, yaitu ketepatan watku datang dokter, penjelasan dokter terkait keadaan pasien dan pemberian pelayanan yang sesuai oleh perawat masih rasakan belum sesuai harapan. Kedatangan dokter yang belum tepat waktu menjadi perhatian lebih bagi responden. Responden merasa menunggu terlalu lama dan bosan. Menurut Laeliyah dan Subekti (2017) waktu menunggu yang dirasakan lama dapat membuat pasien merasa tidak puas dengan pelayanan yang diberikan. Selain itu, ketika dokter datang terlambat, waktu konsul menjadi lebih singkat.

Dimensi dengan nilai kesenjangan terendah kedua adalah dimensi assurance. Responden merasa bahwa pelayanan terkait dimensi assurance belum sepenuhnya sesuai dengan yang mereka harapankan. Dimensi ini lebih menekankan pada aspek pengetahuan, kesopanan, dan upaya untuk memberikan rasa aman kepada responden sehingga responden merasa terjamin dengan pelayanan yang diperoleh. Berdasarkan hasil penelitian pada Tabel 2 dapat diketahui unsur yang menyumbangkan nilai negatif adalah catatan medis pasien, kerahasiaan pasien, dan biaya pelayanan. Setiap pasien yang berobat ke poliklinik saraf Rumah Sakit Bhayangkara H. Samsoeri Mertojoso Surabaya memiliki catatan medis. Namun yang menjadi kendala terkadang ada catatan medis pasien yang lama diantarkan ke poliklinik. Untuk kerahasiaan pasien, perawat belum ada menyampaikan secara lisan mengenai terjaminnya kerahasian pasien secara langsung kepada pasien. Sedangkan untuk biaya sendiri masih dirasakan belum terjangkau sehingga menimbulkan ketidakpuasan. Sesuai dengan hasil penelitian Adil, Syamsum, dan Najib (2016) mengenai pengaruh dari kualitas pelayanan yang diberikan dan biaya pengobatan terhadap tingkat kepuasan dan loyalitas pasien di Rumah Sakit Umum Daerah Kota Bogor tahun 2016 yang menyatakan bahwa besaran biaya yang dikeluarkan oleh pasien untuk mendapatkan pelayanan kesehatan berpengaruh langsung terhadap tingkkat kepuasan pasien.

Dimensi tangible adalah dimensi yang paling mudah untuk dinilai karena responden melihat secara nyata unsur-unsur yang dinilai. Penilaian pertama yang dibuat responden terhadap dimensi tangible dapat mempengaruhi tingkat kepuasan responden selanjutnya. Menurut Tjiptono (2014) bukti fisik adalah wujud kenyataan dari pelayanan yang meliputi fasilitas, peralatan, penampilan petugas dan informasi yang berpengaruh terhadap puas tidaknya seorang konsumen. Faktor tangible merupakan salah satu faktor dari dimensi kualitas pelayanan yang memiliki pengaruhi yang signifikan terhadap tingkat kepuasan pasien.

Berdasarkan hasil penelitian, poliklinik saraf Rumah Sakit Bhayangkara H. Samsoeri Mertojoso Surabaya dinilai oleh responden belum mampu memberikan pelayanan yang memenuhi harapan mereka. Ruang tunggu di poliklinik saraf masih dirasakan kurang nyaman dan tempat duduk yang disediakan masih kurang. Selain itu ruang tunggu juga masih dirasakan sangat panas. Menurut Alicia (2013) keadaan sarana prasarana, salah satunya ruang tunggu pasien, mempengaruhi tingkat kepuasan pasien. Ruang tunggu yang nyaman, bersih dan tempat duduk yang mencukupi akan meningkatkan kepuasan pasien. Namun jika ruang tunggu tidak nyaman, tidak bersih dan fasilitas yang dimiliki kurang tentunya akan menimbulkan ketidakpuasan bagi pasien. Papan petunjuk yang terdapat di poliklinik saraf juga dirasakan belum memberi kepuasan kepada responden. Masih terdapat responden yang bingung mengenai papan petunjuk yang tersedia.

Dimensi empathy adalah dimensi yang menilai mengenai hubungan langsung antara pasien dengan dokter dan/atau perawat sehingga menimbulkan pemahaman secara emosional. Dimensi empathy menilai bagaimana dokter dan perawat memperhatikan dan memperlakukan pasien. Di poliklinik saraf Rumah Sakit Bhayangkara H. Samsoeri Mertojoso Surabaya, unsur empathy menjadi penyumbang nilai negatif terbesar. Artinya, responden belum merasa puas karena apa yang mereka harapankan melebihi dari kenyataan yang diterima. Perasaan pasien yang merasa bahwa petugas kurang bersungguh-sungguh dalam mendengarkan keluhan dan memberikan informasi, 
serta waktu konsultasi yang dirasakan terlalu cepat menjadi faktor yang memicu timbulnya rasa ketidakpuasan.

Hasil penelitian ini sesuai dengan pendapat Wira, et al (2014) yang menyatakan bahwa hal terpenting di dalam pemberian pelayanan asuhan keperawatan adalah memahami perasaan pasien dimana perawat bersedia mendengarkan keluhankeluhan pasien. Apabila pasien merasa tidak didengarkan, maka pasien akan rasakan ketidakpuasan. Selain itu, komunikasi yang kurang koperatif antara petugas rumah sakit juga akan menimbulkan ketidakpuasan.

Berdasarkan hasil penelitian diketahui bahwa dimensi responsiveness adalah dimensi yang telah mampu memenuhi harapan responden. Hal ini menunjukkan bahwa, petugas kesehatan telah memberikan respon yang baik kepada pasien. Menurut Hakim (2017) tingkat kepuasan pasien berhubungan dengan bagaimana cara petugas berinteraksi dan memberikan respon kepada pasien. Semakin baik respon petugas maka pasien akan merasa semakin nyaman. Pendapat ini juga sejalan dengan Putri dan Supriyanto (2016) menyatakan bahwa pemberian pelayanan yang responsif kepada pasien akan memberikan pengaruh yang positif terhadap kepuasan pasien.

\section{SIMPULAN}

Kualitas pelayanan merupakan salah satu hal yang vital yang mempengaruhi keberlangsungan dari poliklinik saraf Rumah Sakit Bhayangkara $\mathrm{H}$. Samsoeri Mertojoso Surabaya. Kualitas pelayanan yang sudah dirasakan baik dan memuaskan akan membantu poliklinik saraf terhindar dari citra yang buruk dan hilangnya jumlah kunjungan. Berdasarkan hasil penelitian diketahui bahwa tingkat kepuasan responden secara umum masuk kedalam kategori sangat puas. Walau tingkat kepuasan sudah baik, namun masih terdapat kesenjangan pada kualitas pelayanan di poliklinik saraf. Kesenjangan terbesar, yang mendapatkan penilaian negatif tertinggi, adalah dimensi empathy. Diurutan selanjutnya terdapat dimensi tangible, assurance, dan reliability. Dimensi reponsivness adalah satu-satunya dimensi yang dinilai oleh responden telah mampu memberikan pelayanan sesuai dengan harapan pelanggan. Selain itu harapannya, rumah sakit dapat meningkatkan kenyaman ruang tunggu di poliklinik saraf, memastikan dokter datang tepat waktu dan memberikan waktu konsultasi yang cukup sehingga pasien merasa tidak terburu-buru.

\section{DAFTAR PUSTAKA}

Adil, A., Syamsun, M. and Najib, M. (2016) 'Pengaruh Kualitas Pelayanan dan Biaya terhadap Kepuasan dan Loyalitas Pasien RSUD Kota Bogor', Jurnal Aplikasi Manajemen, 14(3), pp. 432-441. doi: 10.18202/jam23026332.14.3.04.

Alicia, Y. K. (2013) 'Faktor- faktor yang Berhubungan dengan Kepuasan Peserta ASKES Sosial dalam Pelayanan Dokter Keluarga PT . ASKES ( Persero ) Kabupaten
Kuantan Singingi 2013', Jurnal Kesehatan Komunitas, 2(2), pp. 100-105. Available at: jurnal.htp.ac.id/index.php/keskom/article/dow nload/53/42/.

Caresya, G. D., Meilawaty, Z. and Hadnyanawati, H. (2016) 'Pengaruh Komunikasi Interpersonal Dokter Gigi-Pasien terhadap Tingkat Kepuasan di Poli Gigi Puskesmas Jember', e-Jurnal Pustaka Kesehatan, 3(3), pp. 547554. Available

at: http://jurnaljam.ub.ac.id/index.php/jam/article /view/931.

Hakim, M. R. (2017) 'Persepsi Nilai Pelanggan dan Kepuasan di Klinik Swasta "X" di Surabaya', Jurnal Administrasi Kesehatan Indonesia, 5(1), pp. 91-98. Available at: https://jurnal.unej.ac.id/index.php/JPK/article/ view/2049/1656

Handini, I. P. and Chalidyanto, D. (2015) 'Customer Gap Pelayanan BPJS Kesehatan Center', Jurnal Administrasi Kesehatan Indonesia, 3(2), pp. 161-169. Available at: https://ejournal.unair.ac.id/JAKI/article/view/1872/137 6.

Hermanti, P. (2017) 'Kepuasan Pelanggan Berdasarkan Dimensi Timeliness Kualitas Jasa Evans Dan Lindsay Dengan Metode Importance Performance Analysis', Jurnal Administrasi Kesehatan Indonesia, 5(1), pp. 82-90. Available at: https://ejournal.unair.ac.id/JAKI/article/view/7053/424 0.

Kotler, P. T. and Armstrong, G. (2014) Principles of Marketing (15th Edition). 15th edn. New Jersey: Pearson Education, Inc.

Kowalska, M. et al. (2017) 'Aging and Neurological Diseases Marta', in Senescence - Physiology or Pathology Figure. IntechOpen, pp. 63-94. doi: 10.5772/32009.

Laeliyah, N. and Subekti, H. (2017) 'Waktu Tunggu Pelayanan Rawat Jalan dengan Kepuasan Pasien Terhadap Pelayanan di Rawat Jalan RSUD Kabupaten Indramayu', Jurnal Kesehatan Vokasional, 1(2), pp. 102-112. doi: 10.22146/JKESVO.27576.

M, L. W., Setiawan, H. and Sirajuddin (2016) 'Analisis Kepuasan Pelanggan Terhadap Pelayanan Pada Alfamidi Bukit Palem Cabang Kota Cilegon', Jurnal Teknik Industri, 4(1), pp. 1-96. Available at: http://jurnal.untirta.ac.id/index.php/jti/article/vi ew/1394/1105.

Menteri Kesehatan Republik Indonesia (2008) Menteri Kesehatan Republik Indonesia Nomor: 129/Menkes/SK/II/2008 tentang Standar Pelayanan Minimal Rumah Sakit Menteri Kesehatan Republik Indonesia, Standar Pelayanan Minimal Rumah Sakit. Indonesia. 10.1017/CBO9781107415324.004

Muala, A. Al (2016) 'The Effect of Service Quality Dimensions on Customers' Loyalty through Customer Satisfaction in Jordanian Islamic Bank', International Journal of Marketing Studies, 8(6), pp. 141-146. doi: 10.5539/ijms.v8n6p141.

Pena, M. M. et al. (2013) 'The use of the quality 
model of parasuraman, zeithaml and berry in health services', Revista da Escola de Enfermagem, 47(5), pp. 1227-1232. doi: 10.1590/S0080-623420130000500030.

Putri, L. M. and Supriyanto, S. (2016) 'Analisis Kesenjangan Pelayanan Pada Pasien Poliklinik Rawat Jalan Menggunakan Customer Window', Jurnal Administrasi Kesehatan Indonesia, 4(2), pp. 117-125. Available at: https://ejournal.unair.ac.id/JAKI/article/view/3179/232 2.

Supartiningsih, S. (2017) 'Kualitas Pelayanan an Kepuasan Pasien Rumah Sakit: Kasus Pada Pasien Rawat Jalan', Jurnal Medicoeticolegal dan Manajemen Rumah Sakit, 6(1), pp. 9-15. doi: 10.18196/jmmr.6122.Kualitas.

Sylviana, D., Diarti, P. and S, P. B. (2014) 'Studi Kualitas Pelayanan Apotek Ditinjau dari Tingkat Kepuasan Konsumen di Kecamatan Sumbersari Jember', e-Jurnal Pustaka Kesehatan, 2(3), pp. 432-438. Available at: https://jurnal.unej.ac.id/index.php/JPK/article/ view/2049/1656.

Tjiptono, F. (2014) Pemasaran Jasa, Prinsip, Penerapan Dan Penelitian. Yogyakarta: Andi Publisher.

Wira, D., Suarjana and Wijaya, G. (2014) 'Hubungan antara Persepsi Daya Tanggap dan Persepsi Empati dengan Kepuasan Pasien di RSUD Wangaya Denpasar', Public Health and Preventive Medicine, 2(2), pp. 150-155. 